\title{
The effect of PETTLEP and traditional mental imagery on handball triple shooting in novice and professional adolescent handball players
}

\author{
Hasan Gharayagh Zandi ${ }^{1}$, Davood Mohammadvalipoor He ris ${ }^{2}$ \\ 1-Assistant Profes sor, Depart ment of Sport Psychology, University of Tehran, Tehran, Iran . \\ 2- M.A. of Sport Psychology, Department of Sport Psychology, University of Tehran, Tehran, Iran (Corresponding \\ Author). \\ E-mail: davoodvalipoor71@ut.ac.ir
}

Recei ve d: $17 / 08 / 2020 \quad$ Acce pted: $05 / 10 / 2020$

\begin{abstract}
Introduction: Mental imagery is one of the psychological skills that sports psychologists recommend athletes to focus on.

Aim: This study aimed to investigate the effects of PETTLEP and traditional mental imagery on handball triple shooting in novice and professional adolescent handball players.

Method: A semi-experimental study was conducted on all novice and professional adolescent handball players in Maragheh, East Azerbaijan Province, Iran, in 2018-2019. By using the revised Movement Imagery Questionnaire (MIQ-R) (Hall and Martin, 1997), 60 people from the statistical population were purposively selected as the sample. The participants were randomly assigned to 5 groups of 12: two groups of traditional mental imagery at the novice and professional levels, two groups of PETTLEP imagery at the novice and professional levels, and a control group. After the 9-meter line test as the pretest, 3 sessions of group training for 7 weeks and then the posttest were performed. The data were statistically analyzed by using the repeated measures ANOVA and the Tukey's test in SPSS-23.
\end{abstract}

Results: The results showed that professional participants in the PETTLEP imagery group significantly outperformed their peers in the traditional imagery group in handball triple shooting $(\mathrm{P}=0.001)$. By contrast, such a significant difference was not observed between the two groups of novice handball players $(\mathrm{P}>0.05)$. The results also indicated that the highest increase in mean score from pretest to posttest was observed among professional handball players in the PETTLEP imagery group.

Conclusion: Mental imagery can effectively improve the performance of athletes. Therefore, it is recommended to be used in combination with physical exercises.

Keywords: Mental imagery, Handball player, Novice, Professional, Athletic performance

How to cite this article : Gharayagh Zandi H, Mohammadvalipoor Heris D. The effect of PETTLEP and traditional mental imagery on handball triple shooting in novice and professional adolescent handball players. Shenakht Journal of Psychology and Psychiat ry. 2020; 7 (5): 1-14 .URL: http://shenakht.muk.ac.ir/article-1-965-en.pdf

Copyright (C) 2018 the Author (s). Published by Kurdistan University of Medical Sciences. This is an open access article distributed under the terms of the Creative Commons Attribution-Non Commercial License 4.0 (CCBY-NC), where it is permissible to download, share, remix, transform, and buildup the work provided it is properly cited. The work cannot be used commercially without permission from the jo urnal. 


\title{
تأثير تصوير سازى ذهنى پتلِ و سنتى بر شوت سهام در هندباليستهاى نوجوان مبتدى و حرفهاى
}

\author{
حسن غر اياق زندى'، داود محمدولى يورهريس \\ ا.استاديار، گروه روان شناسى ورزشى، دانشكاه تهران، تهر ان، ايران.
}

r. كارشناس ارشد روان شناسى ورزشى، كروه روان شناسى ورزشى، دانشكاه تهران، تهران، ايران (مولف مسئول). ايميل: davoodvalipoor71@ut.ac.ir

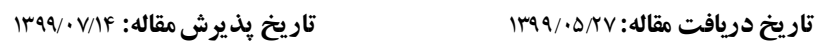

جكيده

مقدمه: يكى از مهارتهاى روانى كه روانشناسان ورزشى آن را به ورزشكاران توصيه مى كند، تصويرسازى ذهنى است.

هدف: اين يُزوهش، درصدد بررسى تأثير تصويرسازى ذهنى سنتى و هِتلِ بر شوت سه كام در هندباليستهاى نوجوان مبتدى و

حرفهاى بود.

روش: روش يُزوهش نيمه تجربى بود. جامعه آمارى شامل كليه بازيكنان نوجو ان هندبال شهرستان مراغه در سال IT I در دو سطح

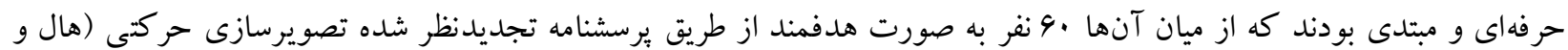

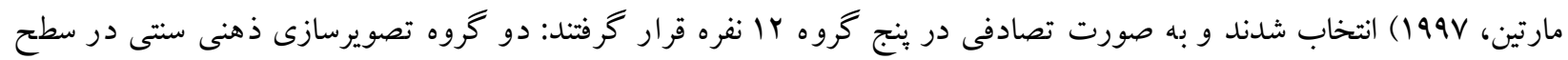

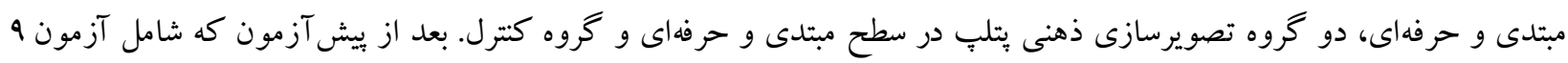

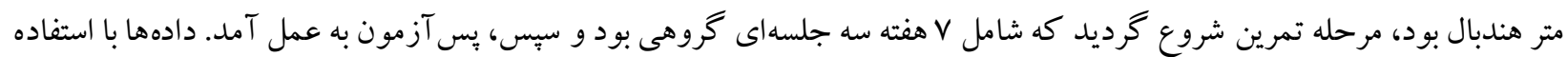

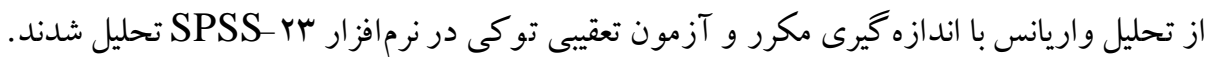

يافتها: نتايج نشان داد بين دو گروه حرفهاى تصويرسازى بتلب و سنتى در عملكرد شوت سه گام هندبال تفاوت معنىدارى وجود دارد

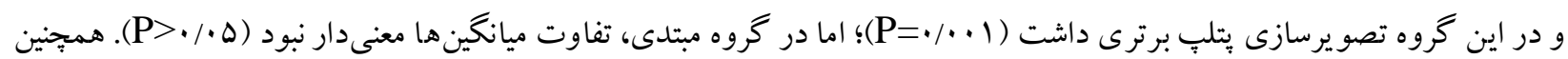

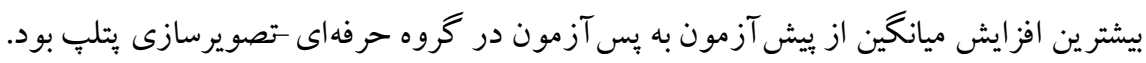
نتيجه كيرى: تصويرسازى ذهنى مى تواند در بهبود عملكرد ورزشى مؤثر واقع شود و استفاده از آن در كنار تمرين بدنى توصيه مىشود. كليدوازهها: تصوير سازى ذهنى، هندباليست، مبتدى، حرفهاى، عملكرد ورزشى 
ورزشى استفاده مىشود، انجام مى گيرد و اغلب توجه كمى به حس جنبشى مى شود و تأكيد اصلى بر جنبههاى

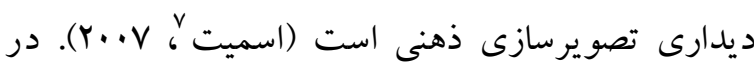
اين نوع تصويرسازى فرد در محيطى آرام و به دور از هيجان به تصور حر كات مى بردازد و اجراى موفقيت آميز مهارت را در غياب حركت بدنى در ذهن مجسم مى كند

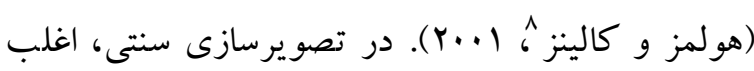
توجه كمى به حس جنبشى مىشود و تأكيد اصلى بر جنبهاى ديدارى تصويرسازى ذهنى است (كامينگك،

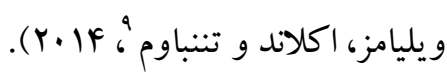

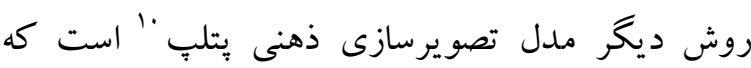

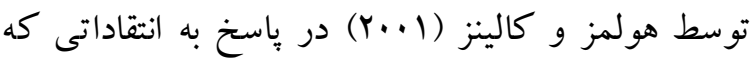

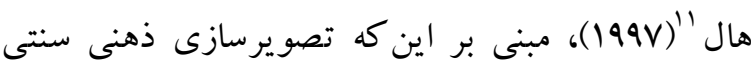
داراى ضعفهايى از جمله خستخكىهاى روحى است،

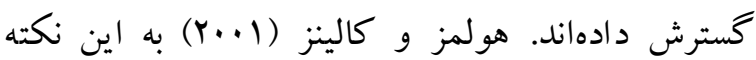
اشاره كردند كه تو ازن عملكر د در آرام سازى بدنى مؤثر نيست و حتى به نظر مىرسد كه كاملاً با حالت بدنى اجراى ورزشكاران مغايرت داشته باشد. به نظر آنها تصويرسازى ذهنى زمانى مؤثر است كه تمامى حواس درگير باشند و احساسات جنبشى در خلال اجراهاى واقعى مهارت، تجربه شوند. اين مدل بر اساس يافتهاى مربوط به علوم اعصاب معرفى شده است و نشان مى دهد كه هميوشانىهاى قابل توجهى در مناطق فعال مغز در طول انجام تصويرسازى ذهنى يك حركت جنبشى و اجراى واقعى همان حركت وجود دارد (ناكس تد با"، (Y.1). نتايج اطلاعات اسكن مغز نشان مىدهد كه در

7. Smith

8 - Holmes \& Collins

9 - Cumming, Williams, Eklund \& Tenenbuam

${ }^{10}$ - PETTLEP

11. Hall

12- Knackstedt

\section{مقلمه} در سالهاى اخير محققان به طور فزايندهاى به اثرات

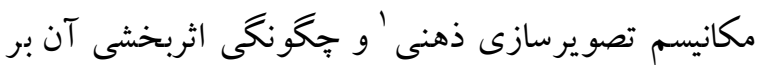
عملكرد، توجه نشان دادهاند و از طرفى تصويرسازى ذهنى يكى از روشهاى مورد علاقه ورزشكاران است. تصويرسازى ذهنى به عنوان استفاده از همه حو اس براى

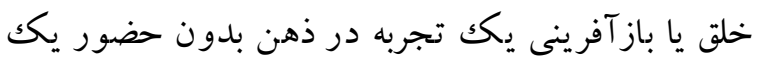

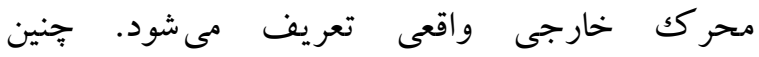
بازآفرينىهايى كه از حافظه فراخو انده مىشوند منجر به اين مى گردد كه فرد تجربهاى جديد از محرككهاى اصلى يا محر ككهاى جديد را در ذهن خود تداعى نمايد

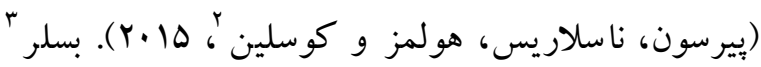
(به نقل از هورنا، ماتسوزاكى، اوتا، شيراشى، هاندا و

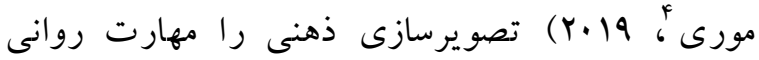
مى داند كه با استفاده آكاهانه از قوه تخيل، تصاوير ذهنى آشكارى در مغز ايجاد و بازسازى مى كند. افراد قادر هستند تصاوير ذهنى را در مورد موضوعات سادهاى مانند شكلها خلق كنند و يا تصاوير ذهنى را براى يادآورى رويدادهاى بيجيجيده ايجاد كنند. ممكن است تصاوير ذهنى بازتاب مستقيم واقعيت باشند. با اين حال مى توان تصاوير ذهنى را در مورد موضوعات خيالى يا رويدادهايى كه

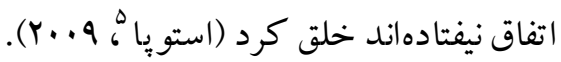
روشهاى مختلف تصويرسازى وجود د دارد كه ابتدايى ترين و ساده ترين روش تصويرسازى، تصويرسازى سنتى "است كه در محيطى دور از محيط واقعى فعاليت ورزشى و همجِنين بدون استفاده از ابزارى كه در ميدان

\footnotetext{
1 - Mental imagery

2 - Pearson, Naselaris, Holmes \& Kosslyn

3 - Besler

4. Haruna, Mat suzaki, Ota, Shiraishi, Hanada \& Mori

5 - Stopa

6- Traditional Imagery
} 
مستلزمات شناختى بيشتر ورزشكار نسبت به حر كات و مهارت هاى ورزشى ديخر دارد شوت سه گام هندبال است. حركت شوت سه گام هندبال براى راست دستان به اين صورت است كه ابتدا توٍ رادر دست گرفته و براى

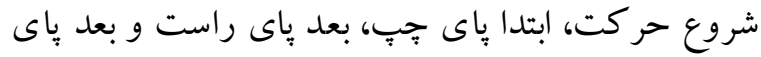
جֶٍ و برش به سمت بالا و جلو و در بالاترين نقطه توبٍ

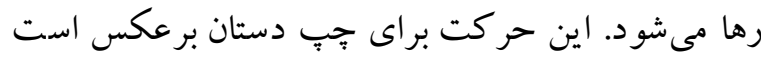

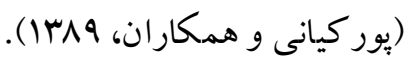

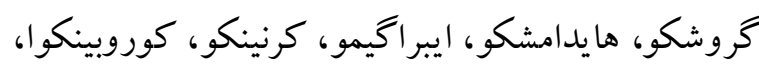
ليونو و وراكسا بr (Y.19) در تحقيقات خود نشان دادند كه فوتباليستهاى حرفهاى در مقايسه با فوتباليستهاى مبتدى از تصويرسازى ذهنى بيشتر استفاده مى كنند. در اين تحقيقات همجنين نشان داده شد كه فوتباليستهاى حرفهاى علاقه بيشترى به استفاده از روشها و و رو تكنيكهاى جديد به منظور افزايش عملكردشان دارند.

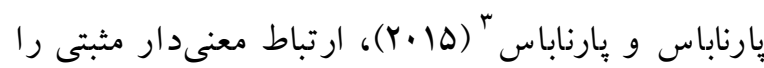
بين تصويرسازى ذهنى و عملكرد تكو اندو كاران يافتند. همجنين آنووار، كامينگ و و ويليامز بررسىهاى خود دريافتند كه مؤلفهاى موجود در

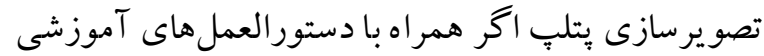
تصويرسازى باشند، منجر به وضوح و شفافيت بيشتر در تصويرسازى حركت نسبت به نسخه سنتى تصويرسازى مى كردد. اين تحقيق اهميت استفاده از تصويرسازى ذهنى و به خصوص بهره بردن از نسخه يتلٍ تصويرسازى براى ورزشكاران را به خوبى نمايان مىسازد. باست، ويليامز،

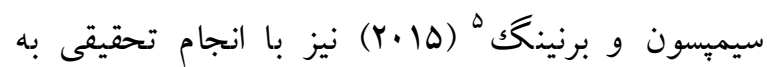
بررسى تأثير تصويرسازى يتلٍ بر يادگيرى مهارتهاى

${ }^{2}$ - Grushko, Haidamashko, Ibragimov, Kornienko, Korobeynikova, Leonov \& Veraksa

3 - Parnabas \& Parnabas

${ }^{4}$ - Anuar, Cumming \& Williams

5 - Post, Williams, Simpson \& Berning
ساختارهاى فعال مغز در طول تمرين بدنى و تصويرسازى ذهنى يكك هميوشانى قابل توجهى وجود دارد (اسميت،

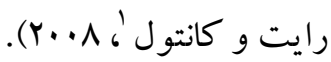
مؤلفهاى مورد نظر در تصويرسازى ذهنى يتلٍ هفت جزء دارند كه شامل مؤ لفهاى جسمانى (بدنى)، محيط،

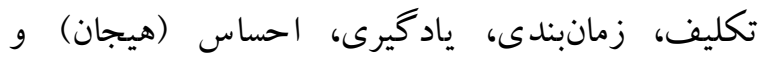
جشم انداز (منظر) مى باشند. اين رويكرد يك جّك ليست براى استفاده از تصوير سازى ذهنى مؤثر براى همه شركت كنندگان و تلاش براى ارائه هم ارزى كاركردى بين عمل تصويربردارى و اجراى واقعى يكك تكليف را فراهم

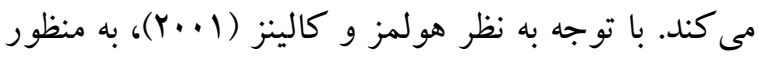
دستيابى به هم ارزى كاركردى از طريق مداخله تصوير سازى ذهنى، بايد بر هفت جزء هِتلٍ تأكيد شود. بـا اين حال برخى از جنبههاى مدل يتلٍ از جمله زمانبندى و جشم اند از در تصويرسازى ذهنى سنتى نيز مورد استفاده

$$
\text { قرار مى گيرند (ناكس تد، (1) }
$$

با توجه به تفاوت نسخهاى تصويرسازى ذهنى يتلٍٍ با مدل سنتى تصويرسازى ذهنى، مىتوان گفت كه در نسخه هاى سنتى عمدتاً بر آنجهه شركت كننده در طول تكليف مىبيند، تمركز دارد. همجنين در روش سنتى اغلب جنبه بيرونى تصويرسازى ذهنى مورد تأكيد است و اين روش اغلب شامل بِيشنهادهايى مبنى بر يذيرفتن وضعيت راحت و به حداقل رساندن عواملى كه باعث حواس يرتى مىشوند، در يكك محيط آرام، قبل از تجسم فعاليت است؛ اما در مدل بتلب حواس بيشترى درگير خواهد شد كه بر اساس نظر هولمز و كالينز هرجه ميزان درگيرى حواس بيشتر شود، موجب افزايش همارزى كار كردى مى گردد. يكىى از حر كات ورزشى شئ كه نياز به

\footnotetext{
1- Smith, Wright \& Cantwell
} 
سنى 11-س| سال بو دند. از بين افراد جامعه، ،4 نفر به

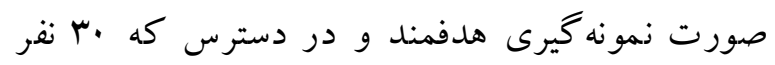

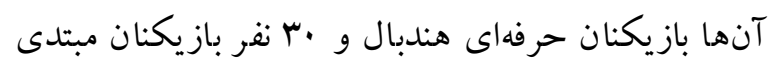
هندبال كه سابقه بازى نداشتند، انتخاب شدند و به طور تصادفى در گروه يتلٍ (مبتدى و حرفهاى) و سنتى (مبتدى و حرفهاى) قرار گرفتند. در ابتدا، رضايتنامه، فرم اطلاعات شخصى و بيرسشنامه توانايى تصويرسازى ذهنى (هال و مارتين '، 199V) بين كليه بازيكنان نوجوان هندبال شهرستان مراغه توزيع كرديد. افراد به صورت كتبى رضايت خود را از شركت در بثزوهش اعلام كردند. افرادى گزينش شدند كه هيج كونه مصدوميت ورزشى نداشتند و هب\% نمره كل در برسشنامه تصويرسازى را كسب كرده بودند. افراد به به به صورت تصادفى در ه گروه Y I نفره تقسيم بندى شدند كه عبارت بودند از گروه تصويرسازى ذهنى پِتٍ

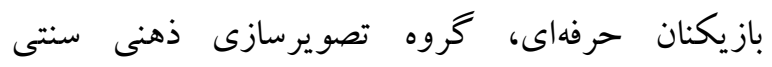
بازيكنان حرفهاى، گروه تصويرسازى بِتلب بازيكنان مبتدى، گرووه تصويرسازى سنتى بازيكنان مبتدى و گر وره

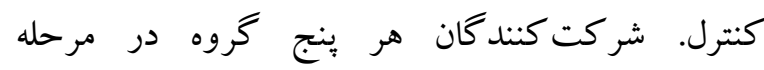
بيش آزمون و در آزمون 9 متر هندبال، · · شوت سه كام

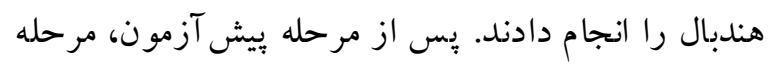

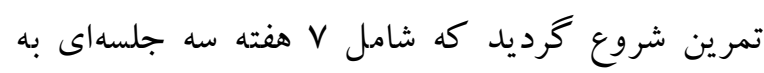
صورت گروهى بود. افراد حاضر در گروه تصويرسازى سنتى در هر جلسه قبل از اجراى تمرين جسمانى، ه دقيقه به تصويرسازى ذهنى به روش سنتى از منظر درونى از

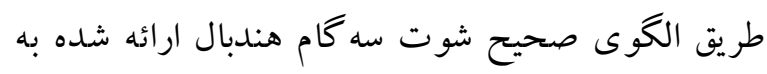
وسيله نوار صوتى ضبط شده مى برداختند. در گرووه تصويرسازى يتلٍ، در هر جلسه قبل از اجراى عملى، صولى

\footnotetext{
${ }^{1}$ - Halland Mart in
}

حركتى بيجيده (يرش طول) برداختند و نتايج تحقيقات آنها نشان داد كه تصويرسازى ذهنى همراه با تمرين فيزيكى در يادگيرى مهارتهاى حركتى بيجيده مؤثر است. طهماسبى بروجنى و ميرحيدرى (|l||) نيز نشان دادند كه تصويرسازى ذهنى بتلب در تعادل ايستا مؤثر و در تعادل يويا تأثير جندانى نداشته است و از طرفى در لهر يس آزمون خروهها تفاوت معنىدارى مشاهده نشد. با وجود فراوانى تحقيقات در مورد تصويرسازى ذهنى به نظر مىرسد كه هنوز خلأهاى متعددى در استفاده بهترين روش براى تصويرسازى ذهنى وجود دارد. در زمينه تصويرسازى سنتى بسيارى از ئزوهشها و نتايج آنها

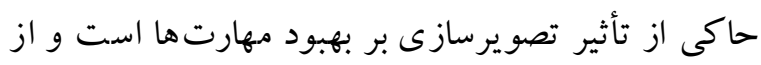
طرفى امروزه محققان به منظور استفاده از تمام حواس در

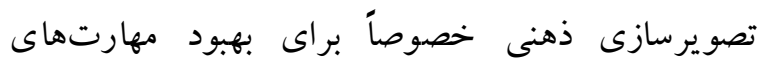

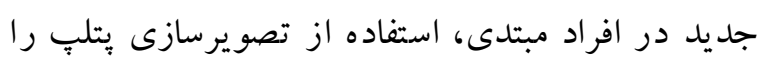

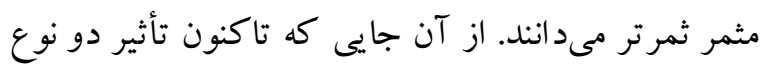
تصويرسازى سنتى و يتلٍ روى عملكرد و دقت شوت سه كام هندبال مورد مقايسه قرار نخرفته است، محقق در اين ثئوهش بر آن بوده است تا تأثير تمرين تصويرسازى سنتى و يتلٍٍ بر عملكرد و دقت مهارت شوت سه كام

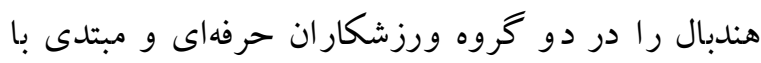
يكديخر مقايسه كند. يزوهش حاضر با توجه به ماهيت و هدف از نوع تحقيقات

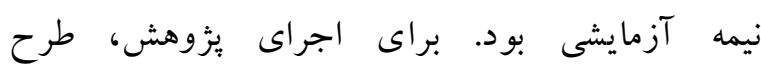

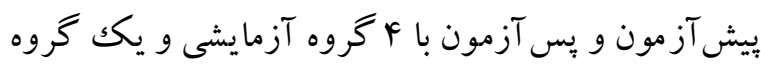
كنترل اجرا شد. جامعه آمارى اين ئزوهش شامل كليه

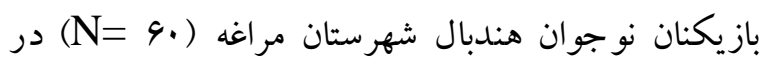
سال VQrا و در دو سطح حرفهاى و مبتدى با ميانگين 
سازه مطلوبى برخوردار است. دامنه بار عاملى در

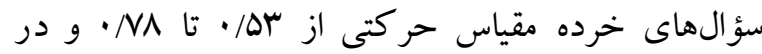
خرده مقياس بينايى از هو/ • تا VA/· تشخيص داده شد. همبجنين نتايج يُوهش نشان داد كه ثبات درونى (س/. •) و يا يايى زمانى (VV) • برسشنامه و خرده مقياس هاى آن مورد تائيد است؛ بنابر اين مى توان نتيجه گرفت كه نسخه فارسى برسشنامه تصويرسازى حركتى از اعتبار و يايايى لازم برخوردار است. و ويليامز، كامينگ، نتومانيس،

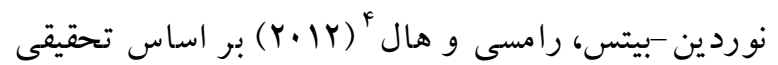
دريافتند كه اين برسشنامه با دار ا بودن روايى تركيبى

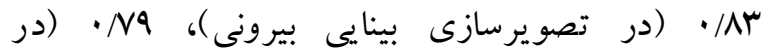
تصويرسازى بينايى درونى) و ه内/ • (در تصويرسازى حركتى) از اعتبار و بايايى لازم برخوردار است. بر اساس

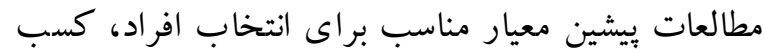

$$
\text { هץ/ نمره كل در اين برسشنامه است. }
$$

نسخه هاى صوتى ضبط شله تصويرسازى ذهنى

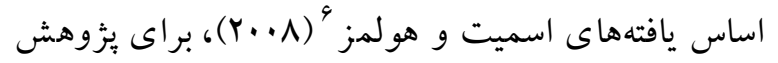
حاضر از نسخه صوتى تصويرسازى سنتى و بتلبٍ به منظور افزايش هم ارزى كاركردى استفاده شد. محتو يات ثبت شده در اين نسخه شامل تمرين آرام سازى در دو دقيقه اول و دستورالعمل صحيح اجراى شوت سه هندبال و تمركز بر دقت در اجراى آن از ابتدا تا انتهاى حركت است كه تنها در مكان مشخص شده براى تمرين و اجراى شوت سه كام، آزمودنى به آن گوش مى دهد. در نسخه يتلبٍ سعى بر آن شد تا بر همه V مؤلفه آن به خصوص (محيط، تكليف و هيجان) تأكيد گردد.

${ }^{4}$ - Williams, Cumming, Ntoumanis, Nordin-Bates, Ramsey \& Hall 5 - Recorded audio version of mental imagery

${ }^{6}$ - Smith \& Holmes
شر كت كنند كان ه دقيقه به تصويرسازى ذهنى به روش يتلب از طريق الكوى صحيح شوت سه گام هندبال ارائه

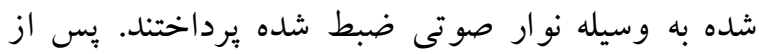
وايان ه دقيقه تمرين تصويرسازى، افراد بلافاصله به مدت ها دقيقه به تمرين جسمانى برداختند؛ و بالاخره گروه كنترل كه در هر جلسه تنها ها دقيقه به تمرين جسمانى شوت سه گام هندبال برداختند. شركت كنندگان در اين تحقيق هفتهاى سه جلسه به تمرين يرداختند و سبِ از افراد هر گروه بِ آزمون به عمل آمد. دادههاى به دست آمده با استفاده از تحليل واريانس با اندازهگيرى مكرر و و آزمون تعقيبى توكى در نرمافزار سب-SPSS تحليل شدند. يرسشنامه تجديد نظرشله تصويرسازى حركتى! جهت ارزيابى توانايى تصويرسازى حر كتى شر كت كنندكان، از يرسشنامه تجديد نظر شده تصويرسازى ذهنى (هال و و

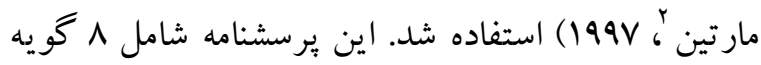
است؛ F كويه ديدارى و F كويه حسى -حر كتى كه هر آيتم متعلق به حركات جداكانهاى است. هر يكك از سؤالات، با مقياس هفت ارزشى ليكرت ارزيابى مى شوند. حداكثر امتيازات فرد در اين دو مؤلفه، عدد وهاست. اين برسشنامه در واقع نسخه اصلاح شده يرسشنامه

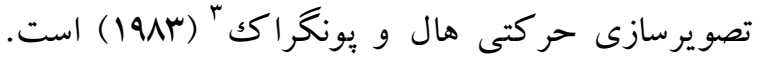
سهر ابى و همكاران (9/1) ) با انجام ئزوهشى نشان دادند كه برسشنامه تجديد نظر شده تصويرسازى حركت با درصد واريانس F.MV در عامل تصويرسازى ذهنى حركتى و Y/99 در تصويرسازى ذهنى بينايى، از اعتبار

\footnotetext{
1- Revised - Movement Imagery Questionnaire

2. Hall \& Martin

${ }^{3}$ - Hall \& Pongrac
} 
امتياز ممكن · F. خواهد بود. از اين آزمون و روش امتيازدهى در تحقيقات كذشته نيز استفاده شده است.

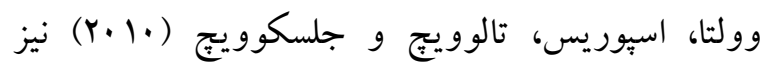
ضريب بايايى اين آزمون راسه/ • برآورد كردهاند.

\section{يافته ها}

در اين مطالعه ·4 نفر از نوجو انان هندباليست شركت كرده بودند كه MF نفر از آنها در قالب ورزشكاران حرفهاى و در دو گرووه تصويرسازى سنتى و تصويرسازى

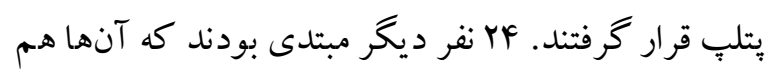
در قالب دو گروه تصويرسازى سنتى و تصويرسازى يتلب قرار گرفتند و با نفر باقى مانده نيز در گروه كنترل قرار كرفتند. توزيع فراوانى سن شر كت كنند كان حاكى از اين بود كه در هر جهار گرووه مداخله و گروه كنترل بين كروهها از نظر توزيع سنى تفاوت معنادارى وجود ندارد.

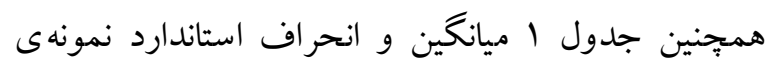
مورد مطالعه در بنج خروه را نشان مىدهد.
آزمون برتاب و متر هندبال: براى به دست آوردن ميزان دقت شوت آزمودنىها از آزمون يرتاب 9 متر در هندبال

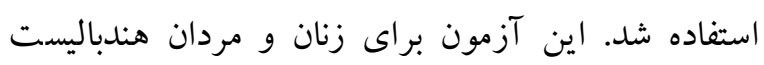
نوجوان و دبيرستانى طراحى شده است. ضريب اعتبار V4 • و ضريب يايايى از طريق آزمون - آزمون مجدد

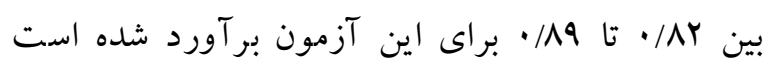
(حسن خلجى، ع اشו). هدف از اجراى اين آزمون، ارزيابى مهارت در بر تاب توٍ براى كسب امتياز است. در اين آزمون، آزمودنى مجاز است تا سه كام مقدماتى

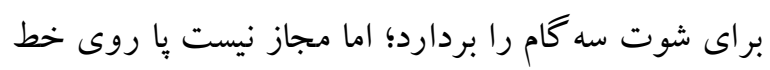

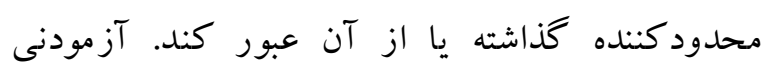

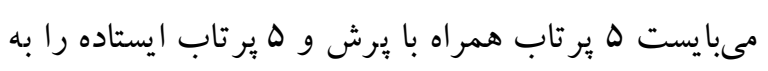

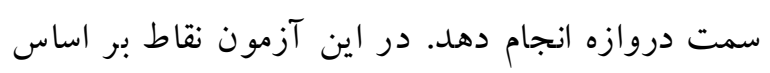
سختى كار امتياز كذارى شدهاند. به بر تابهايى كه خارج از دروازه بوده و يا قبل از ورود به دروازه به زمين

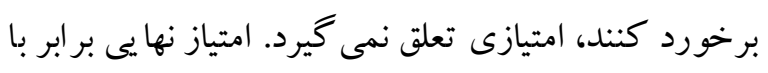

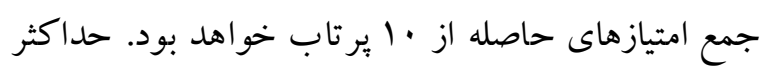

جدول انتايج ميانكين و انحراف استاندارد ينج كروه مورد يزوهش

\begin{tabular}{|c|c|c|c|c|c|c|c|c|c|c|}
\hline \multicolumn{2}{|c|}{ كنترل } & \multicolumn{2}{|c|}{ 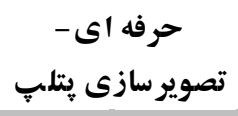 } & \multicolumn{2}{|c|}{ تصوير سازى سنتى ایى - } & \multicolumn{2}{|c|}{ تصوير سازى بتلبٍ } & \multicolumn{2}{|c|}{ تصوير سازى سنتى - مبتدى } & \multirow[t]{2}{*}{ كروه } \\
\hline انحراف & ميانكين & انحراف & ميانكين & انحراف & ميانكين & انحراف & ميانكين & انحراف & ميانكين & \\
\hline$r / \Delta r$ & $r 1 / \cdot \Lambda$ & rNG & rV/AT & $1 / M$ & YN/QA & $r \mu$. & $191 .$. & $r / 91$ & $\mid \Delta / \Delta \lambda$ & קيش آزمون \\
\hline$r / r q$ & YYND & INA & $r q / \Delta \Lambda$ & $1 / 4 \wedge$ & $r 1 / .$. & $1 / 11$ & $19 / \wedge r$ & $r / 190$ & IV/D. & پِس آزمون \\
\hline
\end{tabular}

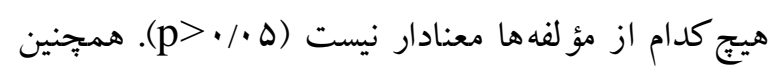
آزمون امباكس نشان داد كه همخنى كوواريانس بين

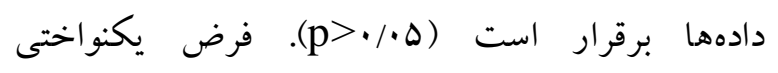
واريانس ها براى دادههاى گرد آورى شده از طريق آزمون
براى تعيين نرمال بودن توزيع دادهها از آزمون كلمو گروف - اسميرنف استفاده گرديد. نتايج نشان داد كه هر ينج گروه در بيش آزمون و يس آزمون شوت سه كام هندبال داراى توزيع نرمال هستند و اين مقدار براى بنى درون 


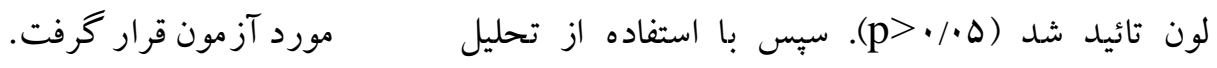

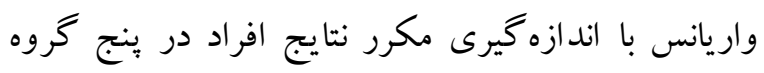

جدول r نتايج آزمون مقايسه بين دو مر حلهى ازدازهكيرى در شوت سه كام هندبال در كروهها

\begin{tabular}{|c|c|c|c|c|c|c|}
\hline مجذور اتا & معنادارى سطح & مقدار F & مجذوروات & درجه آزادى & مجذوروات & منبع اثر \\
\hline.$/ 9$ & $\cdot / \cdot$ & IYF/AG & $9 V F / \pi$. & f & r99V/19 & كروه \\
\hline- & - & - & $\Delta K$. & $\Delta \Delta$ & $r q V / . r$ & خطا \\
\hline$\cdot / M$ & $\cdot / \cdot$ & $r q r / l r$ & $111 / / . r$ & 1 & $111 N / \cdot r$ & زمان \\
\hline$\cdot / 1 \Delta$ & $\cdot / \cdot$ & $V \Delta / A r$ & $r \mid \Delta / 94$ & r & $\Lambda G Y / \Delta V$ & زمان × كروه \\
\hline- & - & - & r/AF & $\Delta \Delta$ & $109 / 4 T$ & خطا \\
\hline
\end{tabular}

نتايج حاكى از اين بود كه در طى زمان ميانگين از

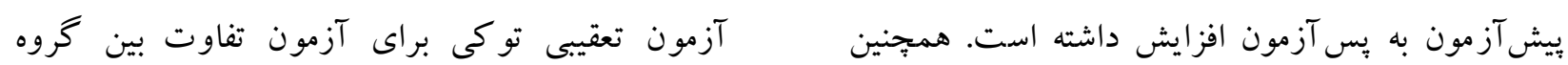

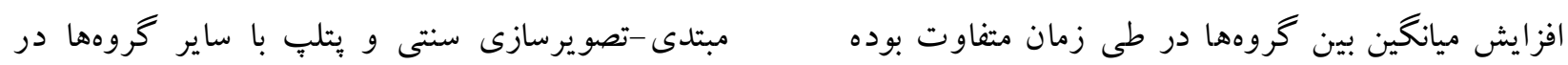

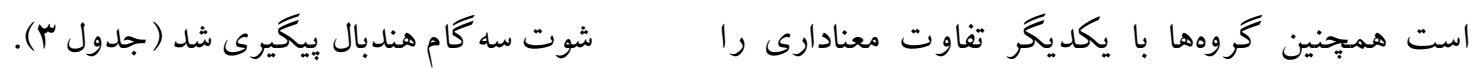

جدول r نتايج آزمون تعقيبى توكى بين كروه مبتدى-تصوير سازى سنتى و كروه مبتدى -تصويرسازى هيتلب

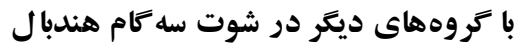

\begin{tabular}{|c|c|c|c|c|c|c|}
\hline \multicolumn{3}{|c|}{ مبتدى - تصويرسازى يتلي } & \multicolumn{3}{|c|}{ مبتدى - تصويرسازى سنتى } & \multirow[b]{2}{*}{ كروه } \\
\hline سنحادارى & خطاى استاندارد & 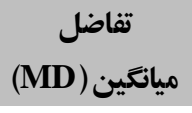 & معنادارى سطح & خطاى استاندارد & 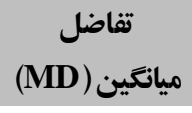 & \\
\hline- & - & - & $\cdot 19$ & $\cdot / 90$ & $-1 / r \Lambda$ & مبتدى - تصويرسازى يتلي \\
\hline$\cdot / \cdots 1$ & $\cdot / 90$ & $11 / M-$ & $\cdot / \cdots 1$ & $\cdot / 90$ & $-1 Y / Y \Delta$ & حرفهاى - تصوير سازى سنتى \\
\hline$\cdot / \cdot \cdot 1$ & $\cdot / 90$ & $10 / V 9-$ & $\cdot / \cdot \cdot 1$ & $\cdot / 90$ & $-I V / I V$ & حرفهاى - تصوير سازى يتلِب \\
\hline.$/ \cdots 1$ & $\cdot / 90$ & $f / \cdots$ & $\cdot / \cdots 1$ & $\cdot / 90$ & $-\Delta / / \Lambda$ & كنترل \\
\hline
\end{tabular}

نسبت به گروههاى حرفهاى سنتى، حرفهاى يتلب و گروه

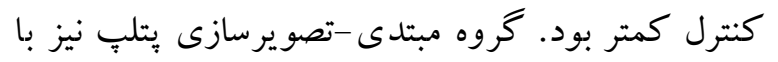
كروههاى ديخر مقايسه شد و نتايج نشان داد كه بين

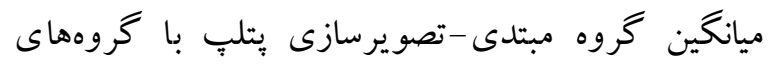

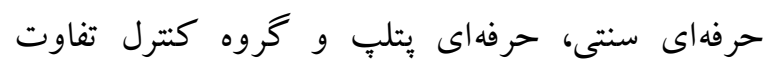

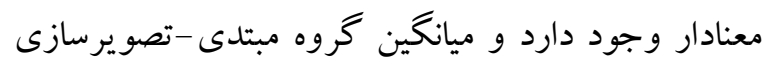

نتايج حاكى از اين بود بين گروه مبتدى-تصويرسازى سنتى با گروه مبتدى -تصو يرسازى بتلٍ تفاوت ميانخين ها

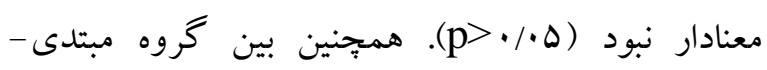
تصويرسازى سنتى با گروههاى حرفهاى سنتى، حرفهاى

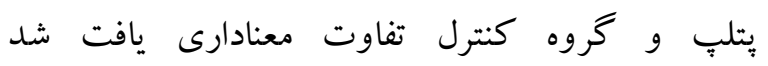

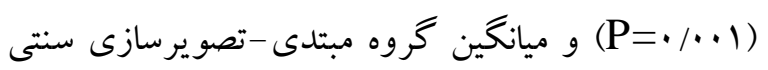




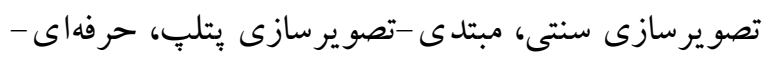

بتلب كمتر از ميانگين گرووهاى حرفهاى سنتى، حرفهاى

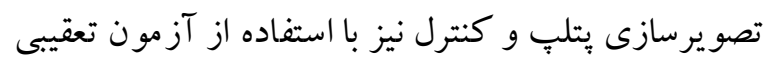

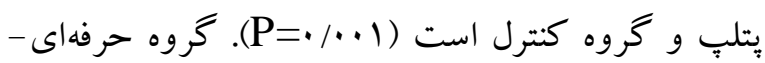
تو كى مقايسه شد ( جدول F) (F).

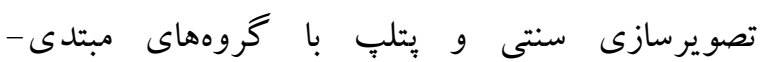

\section{جدول ع نتايج آزمون تعقيبى توكى بين كروه حرفهاى-تصوير سازى سنتى و حرفه اى -تصوير سازى پيتلٍ با كروههاى ديكر در شوت سه كام هندبال}

\begin{tabular}{|c|c|c|c|c|c|c|}
\hline \multicolumn{3}{|c|}{ حرفهاى - تصوير سازى يتلي } & \multicolumn{3}{|c|}{ حرفهاى - تصوير سازى سنتى } & \multirow[b]{2}{*}{ كروه } \\
\hline معنادارى سطح & استاندارد & ميانكين (MD) & معنادارى سطح & خطاى استانارد & ميانكين (MD) & \\
\hline$\cdot / \cdots 1$ & $\cdot / 90$ & $\mathrm{IV} / \mathrm{IV}$ & $\cdot / \cdot \cdot 1$ & $\cdot / 9 \Delta$ & $I r / r \Delta$ & مبتدى - تصويرسازى سنتى \\
\hline$\cdot / \cdots 1$ & $\cdot / 90$ & $10 / v 9$ &.$/ \cdot 1$ & $\cdot / 90$ & $11 / M$ & مبتدى - تصويرسازى يتلي \\
\hline- & - & - & $\cdot 1 \cdot \cdot 1$ & $\cdot / 90$ & $-r / a r$ & حرفهاى - تصويرسازى يتلي \\
\hline$\cdot / \cdots 1$ & $\cdot / 90$ & $11 / 29$ &.$/ \cdot \cdot 1$ & $\cdot / 90$ & $V / M$ & كنترل \\
\hline
\end{tabular}

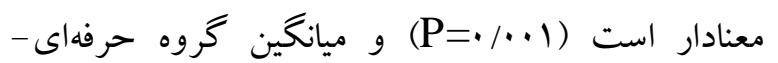
تصويرسازى يتلٍ بيشتر از ميانگين گرووهاى مبتدى تصويرسازى سنتى، مبتدى-تصويرسازى يتلٍ و كنترل است. همجنين ميانگين گروه حرفهاى -تصو يرسازى يتلب بيشتر از ميانگين گروه حرفهاى-تصويرسازى سنتى است ميت

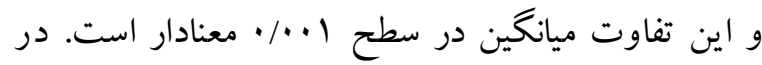

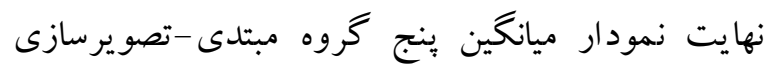
سنتى، مبتدى -تصويرسازى بتلٍ، حرفهاى -تصويرسازى له

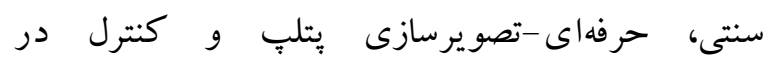
بيش آزمون و بِ آزمون شوت سه گام هندبال در نمودار ا نشان داده شده است. اين نمودار نشان مىدهد كه كه بيشتر ين افزايش ميانگين از بيش آزمون به هيس آزمون در

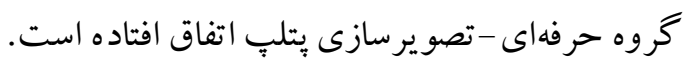

نتايج حاكى از اين بود كه تفاوت ميانگين بين گروه

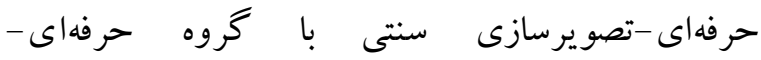

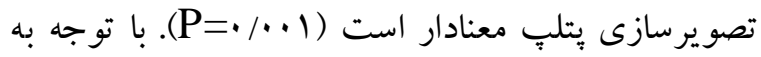
منفى بودن تفاوت ميانگين مىتوان كفت كه ميانگين گروه حرفهاى -تصويرسازى سنتى كمتر از ميانگين گروه حرفهاى -تصو يرسازى بتلٍ است؛ اما تفاوت ميانخين بين كروه حرفهاى -تصويرسازى سنتى با گروههاى مبتدى تصويرسازى سنتى، مبتدى -تصويرسازى يتلٍٍ و كنترل

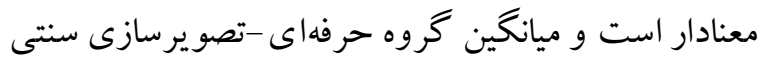

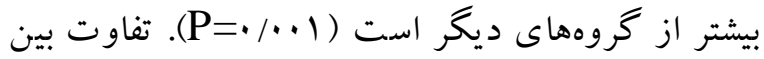
كروه حرفهاى -تصويرسازى بتلب با گروههاى مبتدى تصوير سازى سنتى، مبتدى -تصويرسازى يتلٍ، حرفهاى تصويرسازى سنتى و كنترل نيز نشان داد كه اين تفاوت 


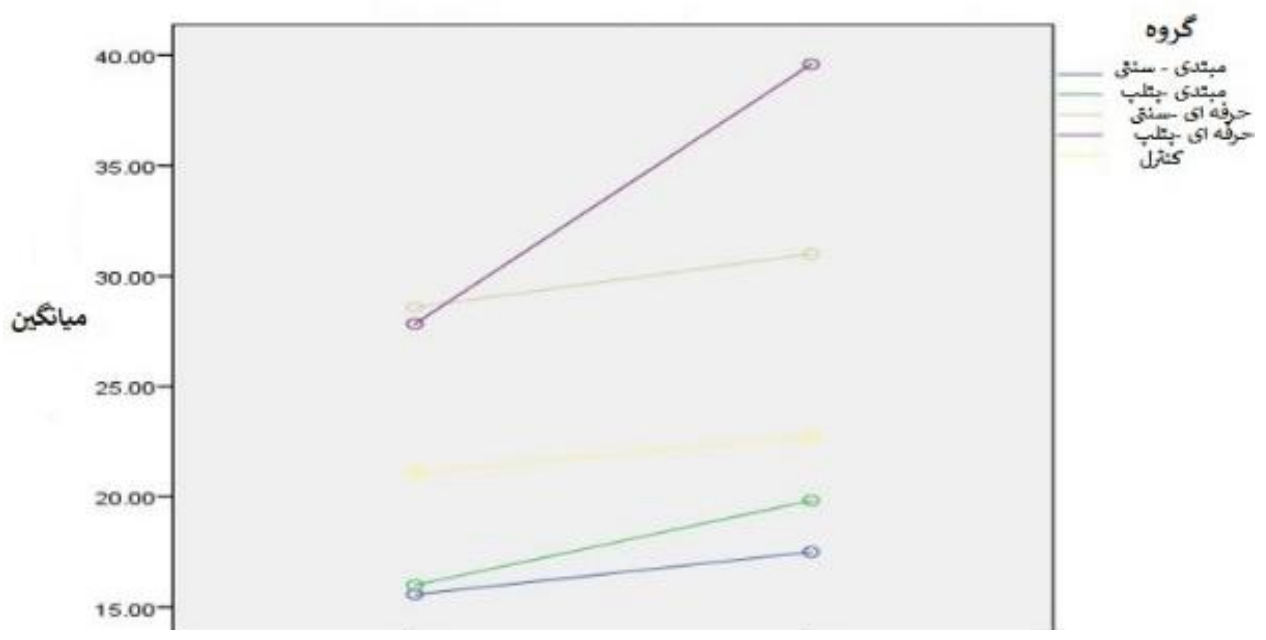

نمودار 1 ميانكَين بيش آزمون و پسآزمون شوت سهام هندبال در پِنج كروه

نتايج با يافتهاى به دست آمده از نتايج اكثر تحقيقات

انجام شده در اين زمينه از جمله يُزوهشهاى انئوار و

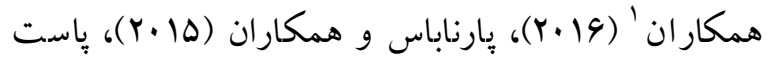

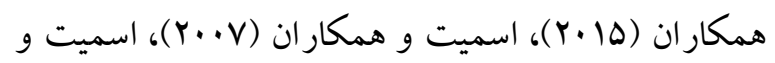

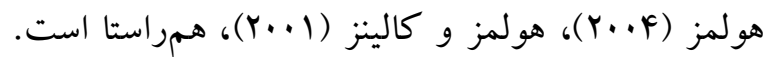
اين تحقيقات نشان مى دهند كه تصويرسازى ذهنى، تأثير مثبتى بر عملكرد ورزشكاران رشتهاى ورزشى مختلف

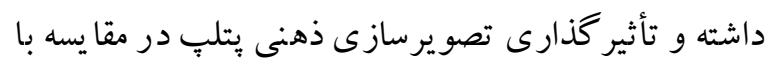
تصويرسازى ذهنى سنتى، بيشتر است. يكى از دلايل اثر گذارى بيشتر تصويرسازى ذهنى بِتٍ را بر اساس نظريه بردازش اطلاعات مىتوان ماهيت كاركردى اين

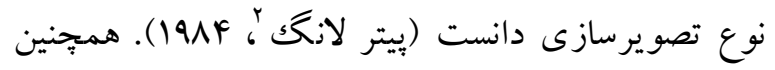
انتظار مى رود با تصويرسازى بر اساس نظريه بيرامونى، مسيرهاى عصبى از طريق اجراى حر كتى به صورت يتلٍ به طور كامل فعال شده باشند؛ ولى در اين مورد كه بين تصويرسازى سنتى و يتلٍ در عملكرد شوت سه گام

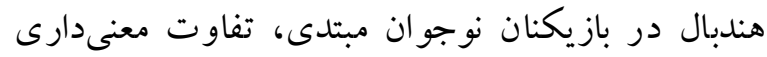

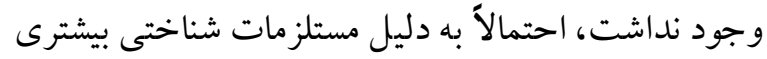

1. Anuar et al

${ }^{2}$ - Peter Long
هدف كلى اين بُزوهش بررسى تأثير تصويرسازى يتلٍٍ و سنتى بر شوت سه گام در هندباليستهاى نو جوان مبتدى و حرفهاى بود. با توجه به نتايج اين تحقيق، هر يكك از ه هون كروه بر اساس روشى تمرين اتخاذ شده در آنها، در بيش آزمون نسبت به يس آزمون بيشرفت داشتند كه بر اساس قانون تمرين هم اين انتظار مىرفت. يافتههاى اين تحقيق نشان داد كه تركيب تمرين بدنى و تصويرسازى ذهنى بتلٍ و تر كيب تمرين بدنى و تصو يرسازى سنتى بر روى شوت سه كام هندباليستهاى نو جوان مبتدى و و حرفهاى تأثير دارد. بدين ترتيب كه تر كيب تمرين بدنى و تصويرسازى ذهنى باعث بهبود مهارت شوت سه گام هندبال در هندباليستهاى نوجوان مبتدى و حرفهاى مى شود. لازم به ذكر است كه در گروه بازيكنان حرفهاى تأثير تصويرسازى بتلٍ بر عملكرد شوت سه گام هندبال بيشتر از تصويرسازى سنتى بوده است ؛ولى در گروه هندباليستهاى نوجوان مبتدى بين تصويرسازى سنتى و يتلبٍ در عملكرد شوت سه گام هندبال در بازيكنان نوجوان مبتدى، تفاوت معنى دارى وجود نداشت. اين 
تصويرسازى ذهنى در مراحل اوليه يادگيرى مهارت

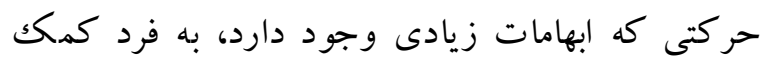
مى كند تا به سؤالات بسيارى درباره اجراى حر كت باستخ بدهد. استفاده از تصوير سازى ذهنى باعث مرور مؤلفههاى نمادين، درك الكوى حركت و كد كذارى حركات

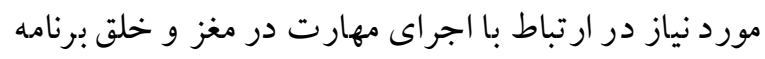
حر كتى در سيستم عصبى مر كزى مى شود. تصويرسازى ذهنى مى تو اند فرد را به طور مؤثرترى در راهبردهاى

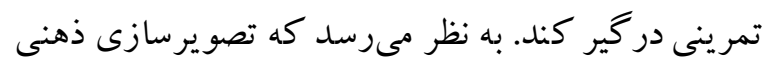

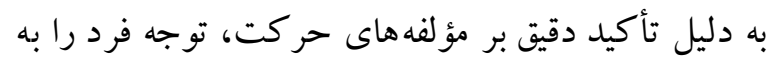

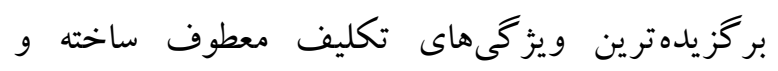

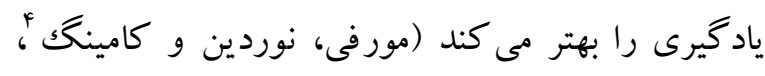

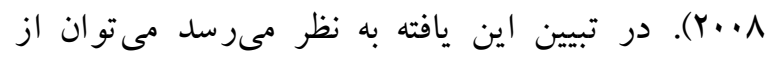

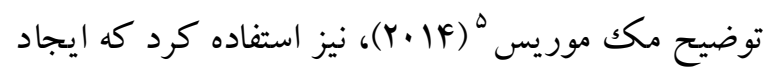

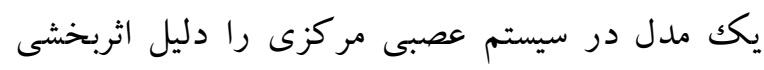

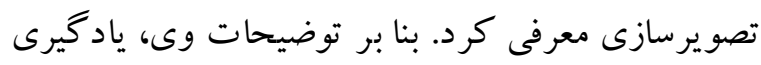

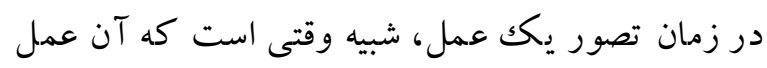

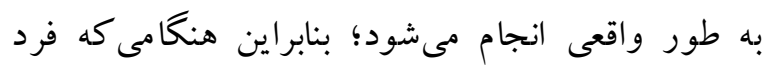
تصوير سازى مى كند از مزاياى تمرين اضافى سود مى برد.

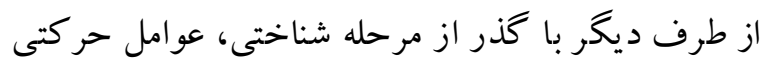

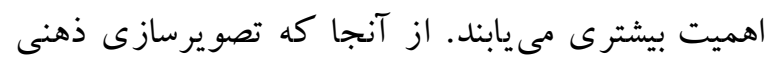

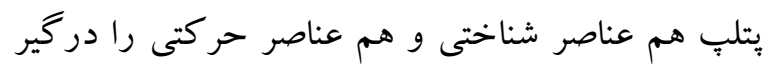
مى كند به نظر مىرسد در مراحل بعدى ياد كيرى نيز

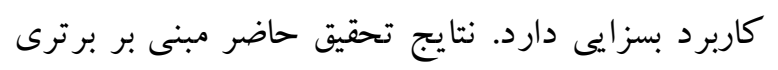

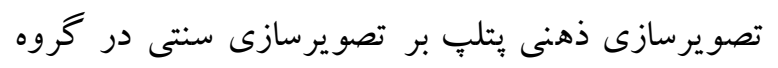

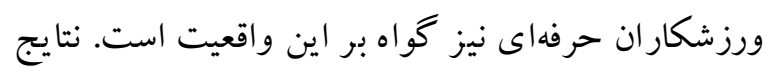
اين بثزوهش حاكى از اين بود كه تفاوت ميانخين بين

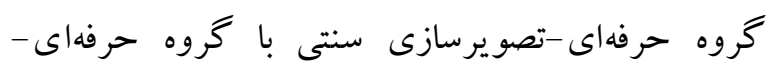

4- Murphy, Nordin \& Cumming 5 - McMorris
بوده است كه براى انجام شوت سه كام هندبال وجود داشته است و به اين دليل كه مبتديان در مراحل اوليه

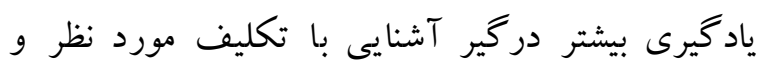

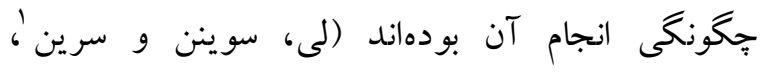

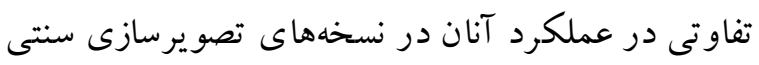

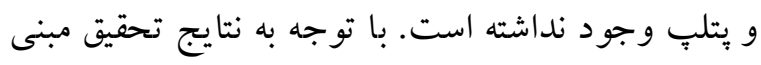

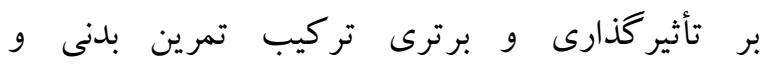
تصويرسازى ذهنى يُّلٍ در بازيكنان حرفهاى به نظر بران مىرسد كه در تصويرسازى ذهنى بتلب همراه با تمرين جون هم عوامل بدنى و هم عناصر شناختى در يادگيرى

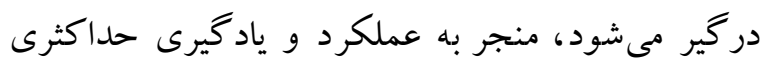

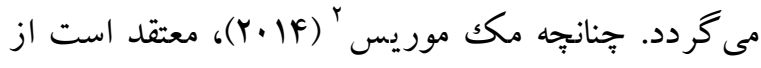
طريق تصوير سازى استفاده از نيمكره راست مغز در رابطه با اطلاعاتى كه درباره آنجه مى بينيم و احساس مى كنيم يا روى آن تمركز داريم، باعث بيشرفت در يادكيرى مى شود. از طرفى محسن افروزه و محمدصادق افروزه (9 (بrا) و و اسميت و همكاران (Y.V)، (Y)، معتقدند تصوير سازى ذهنى مى تواند يكى از فنون بسيار مقبول براى افزايش عملكرد جسمانى باشد و حتى كاركرد مشابه تمرينات جسمانى مخصوصاً در اوايل ياد گيرى را داشته باشند. در تحقيق تراني

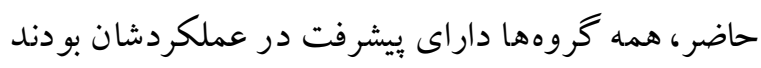

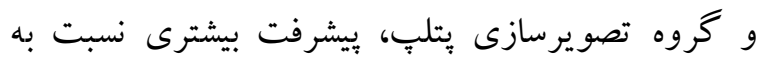

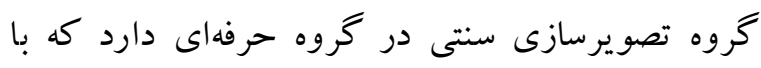
توجه به نظر محققان شناختى نظير مورانّ و همكاران

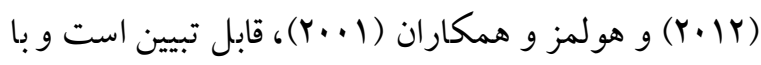
نتايج اين تحقيقات همراستا است. آنها معتقدند كه هـ

\footnotetext{
1- Lee, Swinnen \& Serrien

2 - Mc Morris

3 - Moran
} 
بتوان در همسانسازى ذهن و نحوه رقابت دانست كه با استفاده از تمامى جزئيات، فرد را وادار مى كند خود رادر محيط واقعى تمرين تصور كند (هولمز و كالينز، (...Y). در نهايت بايد به تأثير تصويرسازى ذهنى در يادگيرى و افزايش دقت مهارتهاى ورزشى اذعان كرد.

\section{نتيجه كيرى}

نتايج حاكى از آن بود كه تصويرسازى بيتلب مؤثرتر از

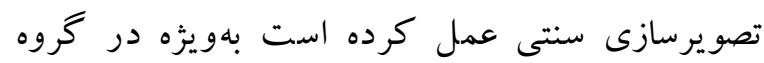
نوجو انان حرفهاى تأثير بيشترى داشته است. به نظر مىرسد نتايج جنين تحقيقاتى بتواند راهخشاى مربيان، محققان و ورزشكار ان در زمينه استفاده از تصويرسازى ذهنى باشد. همجنين انجام مطالعات تصويرسازى ذهنى به طور گستردهاى براى استفاده در مداخلات تصويرسازى متنوع و متفاوت است. اين تنوع باعث ايجاد دشوارى هايى در مطالعات انجام شده و عدم قطعيت در مورد اين كه جه روشى بايد دنبال شود، شده است. بِّ نياز است كه اين مداخلات براى اطلاعرسانى به منظور توصيههاى كاربردى به روز شود. با توجه به يافتهاى اين يُزوهش، نقش تصويرسازى ذهنى بيش از بيش مورد توجه قرار گر فته و تأكيد بر استفاده از آن در كنار تمرين

$$
\text { بدنى توصيه مى شود. }
$$

\section{سياسگز ارى}

يُزوهش حاضر بركرفته از ياياننامه كارشناسى ارشد

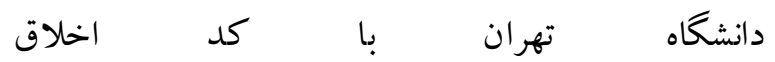
IR.SSRI.REC.1397.272 از بزوهشگاه تربيت بدنى لهران و علوم ورزشى است. در بايان از تمام كسانى كه ما رادر انجام اين بثزوهش يارى فرمو دند، كمال تشكر را داريم.
تصويرسازى يتلٍ معنادار است و با توجه به منفى بودن تفاوت ميانگين مى توان كفت كه ميانگين گروه حرفهاى تصويرسازى سنتى كمتر از ميانگين گروه حرفهاىتصويرسازى بتلب است؛ اما تفاوت ميانگين بين گروه

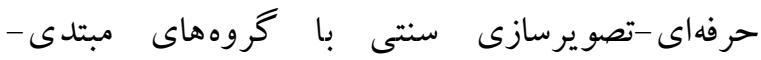
تصويرسازى سنتى، مبتدى -تصويرسازى يتلب و كنترل

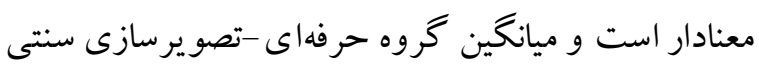
بيشتر از گروههاى ديخر است. اين نتايج با نتايج تحقيقات

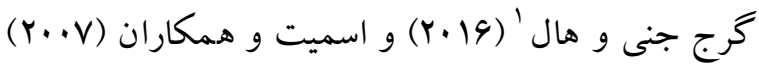
همسو مىباشند. اين نتايج از مدل تصويرسازى ذهنى به روش يتلٍ حمايت مى كنند. در اين بزٔوهش با توجه به اينكه نتايج حاكى از اين بود

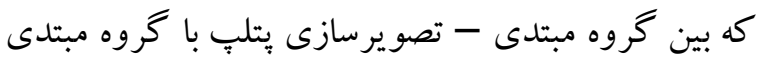
- تصويرسازى سنتى، تفاوت ميانخينها معنىدار نبود، مىبايست تحقيقات بيشترى در اين زمينه صورت گيرد تا مشخص شود كه تأثير گذارى هر كدام از دو نوع نسخه تصويرسازى با توجه به نوع ورزش و تكليف مدنظر و رده سنى شركت كنندگان در پئوهش به جه صورت است. از سو يى ديخر يُزوهش هايى در تكاليفى مثل برش

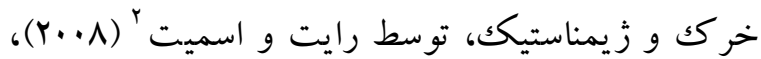
انجام شد كه تكاليف قدرتى و بيجيده بودند و در اين تكاليف تصويرسازى ذهنى پيتلٍ در عملكرد افراد تأثير جندانى نداشت. شايد يكى از دلايل اين موضوع مربوط به ماهيت تكليف كه در قالب قدرت، دقت و سازماندهى آنها است، باشد. همجِنين در اين بُزوهش مشخص شد كه بيشترين افزايش ميانخين از بيش آزمون به هي آزمون در گروه حرفهاى -تصويرسازى يتلب اتفاق افتاده است.

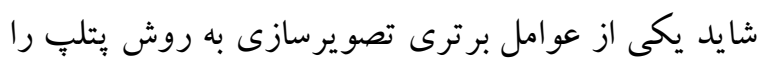

\footnotetext{
1 - Gregg Jenny, Hall

2-Wright and Smith
} 


\section{References}

Afroozeh M, Afroozeh M. (2010). Comparison of PETTLEP and traditional mental imagery in learning badminton short service skills (backhand). Joumal of development and motor learning 6(1), 5-20. (In Persian)

Anuar N, Cumming J, Williams SE. (2016). Effects of applying the PETTLEP model on vividness and ease of imaging movement. Joumal of Applied SportPsychology, 28(2), 185-198.

Anuar N, Williams SE, Cumming J. (2018). Comparing PETTLEP imagery against observation imagery on vividness and ease of movement imagery. International Journal of Sport and Exercise Psychology, 16(2), 150163.

Cumming J, Williams S, Eklund R, Tenenbuam G. (2014). Imagery. Encyclopedia of sport and exercise psychology, 369-373.

Driskell JE, Copper C, Moran A. (1994). Does mental practice enhance performance? Joumal of applied psychology, 79(4), 481.

Gregg MJ, Jenny O, Hall CR. (2016). Examining the relationship between athletes' achievement goal orientation and ability to employ imagery. Psychology of Sport and Exercise, 24, 140146.

Gushko AI, Haidamashko IV, Ibragimov RR, Komienko DS, Korobeynikova EY, Leonov SV, Veraksa AN. (2016). Does the motivation, anxiety and imagery skills contributes to football (soccer) experience. Procedia-social and behavioral sciences, 233, 181-185.

Hall CR, Martin KA. (1997). Measuring movement imagery abilities: a revision of the movement imagery questionnaire. Journal of mental imagery, 21(1-2), 143-154.

Hall CR, Pongrac J. (1983). Movement imagery questionnaire. Faculty of Physical Education, University of Westem Ontario, London, Ontario.

Haruna M, Matsuzaki M, Ota E, Shiraishi M, Hanada N, \& Mori R. (2019). Guided imagery for treating hypertension in pregnancy. Cochrane Database of Systematic Reviews, (4).

Holmes PS, Collins DJ. (2001). The PETTLEP approach to motor imagery: A functional equivalence model for sport psychologists. Joumal of applied sport psychology, 13(1), 6083.

Knackstedt P. (2011). Optimal timing of a PETTLEP mental imagery intervention on a dart throwing task: The University of North Carolina at Greensboro.

Lee TD, Swinnen SP, Serrien DJ. (1994). Cognitive effort and motor leaming. Quest, 46(3), 328344.

McMorris T. (2014). Acquisition and performance of sports skills:John Wiley \& Sons.

Moran A, Guillot A, MacIntyre T, Collet C. (2012). Re- imagining motor imagery: Building bridges between cognitive neuroscience and sport psychology. British Journal of Psychology, 103(2), 224-247.

Murphy SH, Nordin S, Cumming J. (2008). Imagery in Sport, Exercise, and Dance. Joumal of Sport Psychology, (29), 2424-2432.

Parnabas V, Pamabas J, Pamabas AM. (2015). The Influence of Mental Imagery Techniques on Sport Performance among Taekwondo Athletes. European Academic Research, 11(11), 14729-14734.

Pearson J, Naselaris T, Holmes EA, Kosslyn SM. (2015). Mental imagery: functional mechanisms and clinical applications. Trends incognitive sciences, 19(10), 590-602.

Post PG, Williams CD, Simpson D, Beming JM. (2015). The effects of a PETTLEP imagery intervention on the learning of a complex motor skill. Journal of Imagery Research in Sportand Physical Activity, 10(1), 19-30.

Pourkiani M, Najafpour M, Miri H. (2010). Handball Training - Technique - Tactics - Rules and Regulations. Bamdad Ketab Publications, Tehran. (InPersian)

Smith D, Holmes PS, Whitemore L, Devonport T. (2001). The effect of theoretically-based imagery scripts on field hockey performance. Joumal of sportbehavior, 24(4), 408-419. 
Smith D, Wright C, Allsopp A, Westhead H. (2007). It's all in the mind: PETTLEP-based imagery and sports performance. Journal of Applied SportPsychology, 19(1), 80-92.

Smith D, Wright Cj, Cantwell C. (2008). Beating the bunker: The effect of PETTLEP imagery on golf bunker shot performance. Research quarterly for exercise and sport, 79(3), 385391.

Sohrabi M, Fooladian J. (2010). Determining the validity and reliability of the Persian version of Revised - Movement Imagery questionnaire. Research in Sports Science, 5, 13-24. (In Persian)

Stopa L. (2009). Imagery and the threatened self: Perspectives on mental imagery and the self in cognitive therapy. Routledge.

Tahmasebi BS, Ghods MS. (2012). The effect of different imagery methods on balance in female students of university of Tehran. Joumal of Development and Motor Learning, 9, 111-127.(In Persian)

Vuleta D, Sporis G, Talovic M, \& Jeleskovic E. (2010). Reliability and factorial validity of power tests for handball players. Sportscience, 3(1), 42.

Williams SE, Cumming J, Ntoumanis N, Nordin-Bates SM, Ramsey R, \& Hall C. (2012). Further validation and development of the movement imagery questionnaire. Joumal of sport and exercise psychology, 34(5), 621-646. 